\title{
Analysis of grey incidence between density of Noctiluca scintillans and factors
}

\author{
Y. J. Xi' ${ }^{1}$ Z. L. Zhao ${ }^{1}$, G. Q. Sun ${ }^{1}$, C. L. Zhao ${ }^{1}$, Y. Wu ${ }^{1}$, L. Yan ${ }^{1}$, C. C. Yang ${ }^{1}$, Z. \\ Z. Wang ${ }^{1}$, X. R. Zheng ${ }^{1}$, B. Zhang ${ }^{1}$, J. D. Mu' ${ }^{1}$,Z. S. Zeng ${ }^{2}$,J. T. Zhang ${ }^{3}, Y$. Q. \\ $\mathrm{Xi}^{4}$ \\ ${ }^{1}$ Ocean and Fisheries Research Institute of Hebei Province, Qin Huang Dao, China \\ ${ }^{2}$ Marine environment monitoring center of the state oceanic administration, Qin Huang Dao, China \\ ${ }^{3}$ Aquatic technical developing company of Hebei Province \\ ${ }^{4}$ Power plant of Qin Huang Dao, China
}

KEYWORD: Noctiluca scintillans, factors, analysis of grey incidence, coastal waters of Hebei province

ABSTRACT: The relation of the density of Noctiluca scintillans and environmental factors was studied. The grey incidence and relational degree of reference sequence and several comparison series were estimated. The results indicated that zooplanktons, Active phosphate Chemical oxygen demand(COD) were the important factors.

\section{INTRODUCTION}

Noctiluca scintillans is one of the largest species of marine Dinoflagellates. It is distributed worldwide in cold and warm waters, being common in neritic and coastal regions. Noctiluca scintillans is a well-known red tide organism. Spectacular blooms result from an interaction of biological features and physical concentration mechanisms. Blooms are mainly formed by an accumulation of the buoyant cells on the sea surface and may be transported by prevailing winds, tides and oceanic currents. Noctiluca scintillans red tides frequently form in spring and summer in many parts of the world, often resulting in a bright pinkish red or orange discolouration of the water. Noctiluca scintillans is also the main tides algae in the coastal waters of Hebei province. Some research shows that internal cause of proliferation of $N$. scintillans is the population base, the external factor is temperature, nutrients and other factors, so the study of relationship between the density of Noctiluca scintillans and environmental factors is of great importance.

Grey relational analysis(Yi 1992) was a quantitative description and comparison method for the development of a system. its purpose is to seek the main relations among the factors in the system, and find the important factors that affect the target value. Grey relational degree was a methed which compared and analyzed various factors in a system to determine the impact of each sub sequences on the same parent sequence. Grey correlation analysis method superior to the regression analysis, the variance analysis and the principal component analysis in its without demanding a large of data and the linear relationship between the data of various factors and characteristic system. 


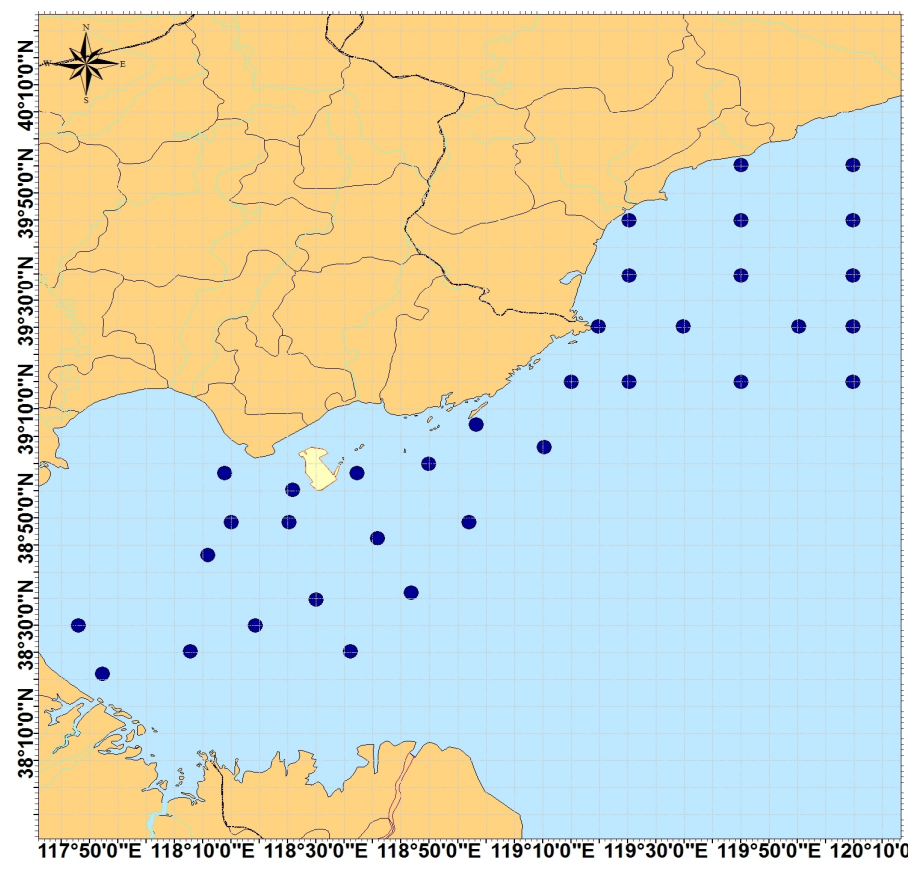

Figure 1. The surveying station

The growth and reproduction of Noctiluc scintillans are affected by various factors in the ocean systemwhich has the characteristics of gray system. So analysis of grey incidence was fit to study the relationship between the density of Noctiluc scintillans and various environmental factors.

\section{METHODS}

\section{Study area}

The present study was conducted in the coastal water of Hebei province in May 2014 where is located in west of the Gulf of Bo Hai $\left(38^{\circ} 07^{\prime} 14^{\prime \prime} \mathrm{N} \sim 40^{\circ} 01^{\prime} 37^{\prime \prime} \mathrm{N}, 117^{\circ} 23^{\prime} 07^{\prime \prime} \mathrm{E} \sim 119^{\circ} 57^{\prime} 02^{\prime \prime} \mathrm{E}\right)$. There were 35 survey stations shown in Fig1. There were 52 rivers and many urban sewage outfalls into the sea along the coast of Hebei which bring a large amount of nutrients into the seawater. The highest river discharges are generally observed in late spring and autumn, whereas the lowest discharge occurs during winter and summer. Inorganic nutrients were mainly due to the river inputs. The temperature shows a regular annual pattern from winter minima as low as $-1.3^{\circ} \mathrm{C}$ in January to summer maxima at $26.3^{\circ} \mathrm{C}$. The river inputs show a high temporal variability that affects salinity which has the characteristics of high in spring and winter, low in summer.

\section{Sampling}

Surface seawater was collected by means of a Water collecting device at about $0.5 \mathrm{~m}$ depths. N.scintillans and net zooplankton samples were collected by type III phytoplankton net (net mouth diameter is $37 \mathrm{~cm}$, net length $1.5 \mathrm{~m}$ ) which is made of silk screen of International Standards No.20 $(0.076 \mathrm{~mm}$ in diameter). Samples obtained by vertically pulling from the seabed to the surface were fixed by $5 \%$ formaldehyde until laboratory analysis.

\section{Sample analysis}

The cells numbers of N.scintillans and zooplankton in the net-samples were accounted using Olympus -VANOX-AHB: LB-2 versatile microscope made in Japan. Seawater temperature, Salinity and Dissolved oxygen were measured by water quality analyzer (USA YSI- 6600) at the site. The seawater samples filtrated through $0.45 \mu \mathrm{m}$ Millipore membrane in site were transported to the laboratory for the analysis of other environmental factors. The analysis for the Ammonia nitrogen, Nitrite, Ni- 
trate and Phosphate were made by Hypobromite oxidation method, Naphthalene ethylenediamine Spectrophotometry, Zinc-cadmium reduction method, Phosphorus molybdenum, blue spectrophotometry, respectively, using instrument of U-V2100 Spectrophotometer. Chemical oxygen demand was determinated by alkaline potassium permanganate method.

The seawater was filtered onto Whatman glass fiber filters and placed into a $20 \mathrm{~mL}$ brown vial containing 10-mL Acetone for chlorophyll a extraction, Chlorophyll a concentration was measured using the same instrument as above. All the methods were shown in the Specification for marine monitoring GB17378- 2007.

\section{data analysis}

In the present study, Analysis of grey incidence was used to inquire into the relationship between the density of $N$. scintillans and various environmental factors. The surveying data was disposed by function of analysis tool in EXCEL, Microsoft. With the density of $N$. scintillans as the parent sequence, the zooplankton $\left(\right.$ ind $\cdot \mathrm{L}^{-1)}$, Temperature $\left({ }^{\circ} \mathrm{C}\right)$, Salinity $(\%)$, Dissolved oxygen $\left(\mathrm{mg}^{\mathrm{L}} \mathrm{L}^{-1}\right)$, Chemical oxygen demand $\left(\mathrm{mg} . \mathrm{L}^{-1}\right)$, Ammonia nitrogen $\left(\mathrm{mg} \cdot \mathrm{L}^{-1}\right)$, Nitrite $\left(\mathrm{mg} . \mathrm{L}^{-1}\right)$, Nitrate $\left(\mathrm{mg} . \mathrm{L}^{-1}\right)$, Active phosphate $\left(\mathrm{mg} . \mathrm{L}^{-1}\right)$ as the Sub sequence $\{\mathrm{xi}(\mathrm{t})\}(\mathrm{I}=1,2, \ldots, 10)$. First of all, Equalization of all data was made. Set the original sequence as below:

$$
x(0)=\{x(0)(1), x(0)(2), \ldots \ldots, x(0)(n)\},
$$

So the average value was acquired as

$$
x(0)=\frac{1}{n} \sum_{k=1}^{n} x(0)(k)
$$

A new sequence was made for the equalization of $x(0)$ as

$$
\begin{aligned}
\mathrm{y}(0) & =\{\mathrm{y}(0)(1), \mathrm{y}(0)(2), \ldots \ldots, \mathrm{y}(0)(\mathrm{n})\} \\
& =\left\{\frac{x(0)(1)}{x(0)}, \frac{x(0)(2)}{x(0)}, \mathrm{K} \mathrm{K}, \frac{x(0)(n)}{x(0)}\right\}
\end{aligned}
$$

When $\mathrm{t}=\mathrm{k}$, the correlation coefficient $\xi_{0 i}(k)(i=1,2, \mathrm{~K} \mathrm{~K}, 11)$ between $\{\mathrm{x} 0(\mathrm{k})\}$ and $\{\mathrm{xi}(\mathrm{k})\}$ was calculated as

$$
\xi_{0 i}(k)=\frac{\Delta_{\min }+\rho \Delta_{\max }}{\Delta_{0 i}(k)+\rho \Delta_{\max }}
$$

Where $\Delta_{0 i}(k)$ was the absolute difference of two sequence in $\mathrm{k}$ time, $\Delta_{0 i}(k)=\mid \mathrm{x} 0(\mathrm{k})-\mathrm{Xi}(\mathrm{k})$ I , $\Delta_{\max }$ and $\Delta_{\min }$ were Maximum and minimum value of all absolute difference ,respectively. $\rho$ was the resolution coefficient and $\rho \in(0,1)$.For increasing Significant difference the value of $\rho$ was determinated as 0.5 . The relational degree was calculated as

$$
\gamma_{0 i}=\frac{1}{n} \sum_{k=1}^{n} \xi_{0 i}(k)
$$

Where $\gamma_{o i}$ was the relational degree between Sub sequence $\mathrm{I}(\mathrm{I}=1,2, \ldots . .11)$ and parent sequence $0, \mathrm{~N}$ was the sequence length.

Association order was formed in order of the size of relational degree which reflect " the pros and cons" relationship between parent sequence and every Sub sequence. 


\section{RESULTS AND DISCUSSIONS}

\section{Results}

The density of N.scintillans and Zooplankton, concentration range of various environmental factors were shown in Table1. The seawater temperature and Salinity varied between $11.48^{\circ} \mathrm{C}$ and $15.91^{\circ} \mathrm{C}$, 29.82 and 31.09, respectively. Dissolved oxygen and COD fluctuated between 6.72 and 9.60, 0.92 and $3.48 \mathrm{mg} \cdot \mathrm{L}^{-1}$. The range of concentration for Ammonia nitrogen, Nitrite, Nitrate, Phosphate and Chlorophyll a were between 0.0021 and $0.0136 \mathrm{mg} \cdot \mathrm{L}^{-1}, 0.0053$ and $0.0916 \mathrm{mg} \cdot \mathrm{L}^{-1}, 0.001$ and 0.574 $\mathrm{mg} \cdot \mathrm{L}^{-1}, 0.001$ and $0.085 \mathrm{mg} \cdot \mathrm{L}^{-1}, 0.00035$ and and $0.011 \mathrm{mg} \cdot \mathrm{L}^{-1}$, respectively. The range of density of Zooplankton and N. Scintillans were 1.080 to $1030.4 \mathrm{ind} \cdot \mathrm{L}^{-1}$ and 4.7 to $9571.3 \mathrm{ind} \cdot \mathrm{L}^{-1}$, respectively.

Table 1. The results of environmental factors

\begin{tabular}{lccc}
\hline factors & range & \multicolumn{2}{c}{ Mean value } \\
\hline Zooplankton* & $1.080 \sim 1030.4$ & 197.90 \\
Temperature** & $11.48 \sim 15.91$ & 13.88 \\
Salinity*** & $29.82 \sim 31.09$ & 30.43 \\
Dissolved oxygen**** & $6.72 \sim 9.60$ & 8.58 \\
COD **** & $0.92 \sim 3.48$ & 1.53 \\
Ammonia nitrogen**** & $0.0021 \sim 0.0136$ & 0.007 \\
Nitrite **** & $0.0053 \sim 0.0916$ & 0.029 \\
Nitrate **** & $0.001 \sim 0.574$ & 0.195 \\
Phosphate**** & $0.001 \sim 0.085$ & 0.029 \\
Chlorophyll a $* * * *$ & $0.00035 \sim 0.011$ & 0.0048 \\
Noctiluca scientillans $*$ & $4.7 \sim 9571.3$ & 617.02
\end{tabular}

Unit : *ind $\cdot \mathrm{L}^{-1} ; * *{ }^{\circ} \mathrm{C} ; * * * \%$ \% $* * * * \mathrm{mg} . \mathrm{L}^{-1}$

By analysis of grey incidence based on the surveying data, the results were shown in Table2. Among various environmental factors, zooplankton was the most important factors influencing the density of Noctiluca scintillans, with the highest correlation degreee being 0.846 . Phosphate and COD were the second and third factors. So a sequence which represented the relationship between Noctiluca scintillans and environmental factors was formed. That was zooplankton $\rangle$ Phosphate $>$ COD $\rangle$ Temperature $\rangle$ Dissolved oxygen $>$ Salinity $\rangle$ Nitrite $>$ Chlorophyll a $>$ Ammonia nitrogen $>\mathrm{Ni}^{-}$ trate.

Table 2. Correlation degree of various factors and density of Noctiluca scientillans

\begin{tabular}{llcc}
\hline Factors & Correlation degree & \multicolumn{2}{c}{ Sequence } \\
\hline Zooplankton & 0.846 & 1 & \\
Temperature & 0.751 & 4 & \\
Salinity & 0.747 & 6 & 5 \\
Dissolved oxygen & 0.748 & & 3 \\
COD & 0.755 & 9 & \\
Ammonia nitrogen & 0.726 & & 7 \\
Nitrite & 0.743 & & 2 \\
Nitrate & 0.724 & & 8 \\
Phosphate & 0.763 & \\
Chlorophyll a & 0.731 &
\end{tabular}

\section{DISCUSSIONS}

Noctiluca scintillans is one of the most common "red tide" organisms. Many studies have been carried out on the relationship between environmental factors and growth and reproduction of $N$. scintillans, but few was reported by the method of Grey theory. In the present study, it was demonstrated that zooplankton was the primary environmental factor which affected the density of Noctiluca scintillans. The result was identical to previous papers (Huang 1996 \&Huang 2002). N.scintillans is a phagotrophic species feeding on bacteria, detritus, protozoans, copepod and eggs of copepod and fish as well as phytoplankton (Kirchner.1996, Nakamura 1998. Quevedo et al. 1999, Strom 
2001). .N.scintillans also possibly affected zooplankton communities by competing for food resources (Nakamura 1998). For example, N.scintillans biomass corresponded to more than $90 \%$ of the zooplankton during bloom periods (Murray \& Suther 1999). So it may be reasonable that zooplankton was the first place for the density of $N$ scintillans among the surveyed factors. Phosphate was the second factor influencing the density of Noctiluca scintillans maybe closely related to the feeding habits of it .Research has shown that food source of about $90 \%$ of Noctiluca scintillans were diatoms (Jiang\&Song,2009), for which phosphate was the essential nutrients. The result obtained in this study revealed that chemical oxygen demand (COD) was the third place in the sequence. A study also indicated that Noctiluca scintillans also fed on other organic substances and bacteria while its bait was lack (Xu 1994), so chemical oxygen demand (COD) plays an important part in the growth and reproduction of Noctiluca scintillans. In this study, the conclusion was acquired that zooplankton, Phosphate and COD were the superiority environmental factors for the density of $N$. Scintillans in coastal seawater of He Bei province .The study would be helpful for exploring the cause of the red tide of Noctiluca Scintillans.

\section{ACKNOWLEDGEMENTS}

This work was financially supported by the Subject of" study on the distribution of pollutants in the coastal waters of Hebei Province" and "Monitoring and assessment of ecological environment of fishery in Bo Hai".

\section{REFERENCES}

[1] D. S .Yi. 1992. Grey theory and Method .Beijing: Petroleum Industry Press.

[2] G. H. Huang et al. 2002.Grey analysis of red tide produced by superior Alga in DaPeng wan Bay, south China Sea 22(6):824-827.

[3] Huang, Weijian et al. 1996. Analysis of grey incidence between seawater physicochemical factors and the growth of Noctiluca scintillans in DaPeng Bay, South China Sea[J] Journal of applied and Environmental Biology 2(2):115-118.

[4] Kirchner, M , Sahling; G.\&Uhlig,G. et al. 1996. Does the red tide forming dinofagellate Noctiluca scintillans feed on bacteria? Sarsia 81:45-55.

[5] L. Jiang \& L. R. Song. 2009. The influence factors on dominant red-tide Algal species succession in QuanZhou Bay. Oceanology and Limnology 40(6):761-76.

[6] Murray, S . \& Suthers. M. 1999. Population ecology Noctilucascitillans Macartney, a red-tide forming dinoflagellate. Aust.J.Mar.Freshw. Res. 50:243-252.

[7] Nakamura, Y.1998. Biomass feeding and production of Noctiluca scintillans in the Seto Inland Sea, Japan. J. Plankton Res.20:2213-2222.

[8] Quevedo, M., Gonzles-Quiros, R.\& Anadon, R. 1999 Evidence of heavy predation by Noctiluca scintillans on Acartia clausi (Copepoda) eggs of the central Cantabrian coast. Oceanol. Acta., 22:127-131

[9] Strom, S. L. 2001. Light- aided digestion grazing and growth in herbivorous protists. Aquat. Microb.Ecol. 23:253-261.

[10]W. J. Xu 1994. Influence on growth of Noctiluca scintillans populations of Salinity, food concentration and temperature. Marine fisheries technology 1: 49 531. 